\title{
SCIENTIFIC VERSUS POLITICAL ECOLOGY
}

\author{
Radivoje Pešićc ${ }^{1}$, Stevan Veinović
}

UDC: $574: 620+504.7$

DOI: $10.24874 / m v m .2017 .43 .03 .02$

\begin{abstract}
Researches and results in many areas cases are not always based on the laws of nature. The National administrations financially support only researches, which are in line with their policy. The last several American presidents have placed ecology in the centre of their presidential campaign. At the beginning of the mandate the presidents were cancelling all plans of its predecessor and define new targets as the only correct and most effective. Global $\mathrm{CO} 2$ emissions from burning fossil fuels have a major impact on the global warming of our planet, say many politicians. Global warming not primarily caused by $\mathrm{CO} 2$, more and more often say by scientists and other politicians. Global warming exists but the cause is the Sun, many scientists say. Ecological consciousness and life rules must be at the development base of every country in the world. Identifying the environmental values of each product is the first step in environmental thinking. The basic maxims of sustainable life on our planet are: NOTHING TOO MUCH AND MODERATION IN ALL THINGS.
\end{abstract}

KEY WORDS: air emission, ecology, energy efficiency, global warming, carbon dioxide

\section{NAUČNA U ODNOSU NA POLITIČKU EKOLOGIJU}

REZIME: Istraživanja i njihovi rezultati, u mnogim oblastima, nisu uvek bazirani na zakonima prirode. Nacionalne administracije finansijski podržavaju samo istraživanja koja su u skladu sa njihovom politikom. Poslednjih nekoliko američkih predsednika postavili su ekologiju u centar svoje predsedničke kampanje. Na početku mandata predsednici otkazuju sve planove svog prethodnika i definišu nove ciljeve kao jedine ispravne i efikasne. Globalne emisije $\mathrm{CO} 2$ iz fosilnih goriva značajno utiču na globalno zagrevanje naše planete, kažu mnogi političari. Dok naučnici i drugi političari sve češće govore da emisija CO2 nije primarni uzrok globalnog zagrevanja. Ekološka svest i pravila života moraju biti osnova razvoja svake zemlje na svetu. Identifikacija ekoloških vrednosti svakog proizvoda je prvi korak u razmišljanju o životnoj sredini. Osnovne maksima održivog života na našoj planeti je: NIŠTA PREVIŠE I UMERENOST U SVEMU.

KLJUČNE REČI: emisija u vazduha, ekologija, energetska efikasnost, globalno zagrevanje, ugljen-dioksid

${ }^{1}$ Received: June 2017, Accepted August 2017, Available on line December 2017 
Intentionally blank

Volume 43, Number 3, 2017 


\title{
SCIENTIFIC VERSUS POLITICAL ECOLOGY
}

\author{
Radivoje Pešić ${ }^{1}$, Stevan Veinović ${ }^{2}$
}

\section{INTRODUCTION}

The countries with the most developed economy defined strategic directions of development in all scientific fields. State administrations define politics of development by adopting appropriate action plans. The adopted action plans are sources of the terms. These terms of references are generally in harmony with nature and contribute to the real advancement of society and nature conservation. Adopted policies, sometimes are guided by the interests of the local economy. Researches and results in these cases are not always based on the laws of nature. The National administrations financially support only researches, which are in line with their policy. Therefore, it is often those researchers, who based their research only to the laws of nature, are left without financial support. In this way suitable political scientific elite are created.

As the world faces increasing environmental challenges, people have sought wisdom and inspiration from a variety of sources. One of those sources is the speech which Chief Seattle delivered nearly 150 years ago. Seattle was a Suquamish Indian from the American northwest who delivered a speech in 1854 to Isaac Williams, the Territorial Governor of Washington, as Williams negotiated with him for the sale of land that was to become the city of Seattle (named in the chiefs honour). The speech has been revered by many people for the inspirational message it provides and for the respect for the environment it displays. Regardless of the exact wording of Seattle's speech, it did contain environmental themes [1]. This speech, which speaks of absolutely everything in the natural world, including every insect and pine needles, has pointed the Chief Seattle as the first ecologist. The speech or "letter" attributed to Chief Seattle has been widely cited as a "powerful, bittersweet plea for respect of Native American rights and environmental values". But this document, which has achieved widespread fame thanks to its promotion in the environmental movement, is of doubtful authenticity.

The Clean Air Act was the first major environmental law in the United States to include a provision for citizen suits. Numerous state and local governments have enacted similar legislation, either implementing federal programs or filling in locally important gaps in federal programs. The act were signed into law by President Lyndon B. Johnson on December 17, 1963. The Clean Air Act is the law that defines EPA's responsibilities for protecting and improving the nation's air quality and the stratospheric ozone layer. The last major change in the law, the Clean Air Act Amendments of 1990, was enacted by Congress in 1990 [2].

\footnotetext{
${ }^{1}$ Radivoje Pešić, Ph.D., prof., University of Kragujevac, Faculty of engineering, Sestre Janjić 6, 34000 Kragujevac, Serbia, pesicr@kg.ac.rs

${ }^{2}$ Stevan Veinović Dr.,Ing., University of Kragujevac, Faculty of engineering, Sestre Janjić 6, 34000 Kragujevac, Serbia,, stevan@kg.ac.rs
} 
The aim of this paper is to analyse the development of US, and UK policy adopted in the field of ecology and energy and to verify these policies with the laws of nature and a scientific ecology.

\section{POLITICAL ECOLOGY}

\subsection{The USA example}

The USA has long been leaders in defining development policies of all the sciences, so and ecology. It is therefore of interest to look at the basic policies which are have been proposed and adopted by administrations of the USA presidents in recent decades.

The last several American presidents have placed ecology in the centre of their presidential campaign. At the beginning of the mandate the presidents were cancelling all plans of its predecessor and define new targets as the only correct and most effective.

In 1987, President Reagan signed the Global Climate Protection Act into law, giving the EPA the lead agency role in developing and proposing a "coordinated national policy on global climate change."

The first President from The Bush family (George H. W. Bush, president from 1989 to 1993) has introduced a strategy in which NATO is responsible for the development of different forms of "non-fossil fuels". The main motive is the strategy "Warfare in the territories in which democracy is introduced", because there is difficulty with supplying the war materials: fuels, lubricants and other operating materials. President Bush were sign the UN Framework Convention on Climate Change in Rio, June 1992 [3].

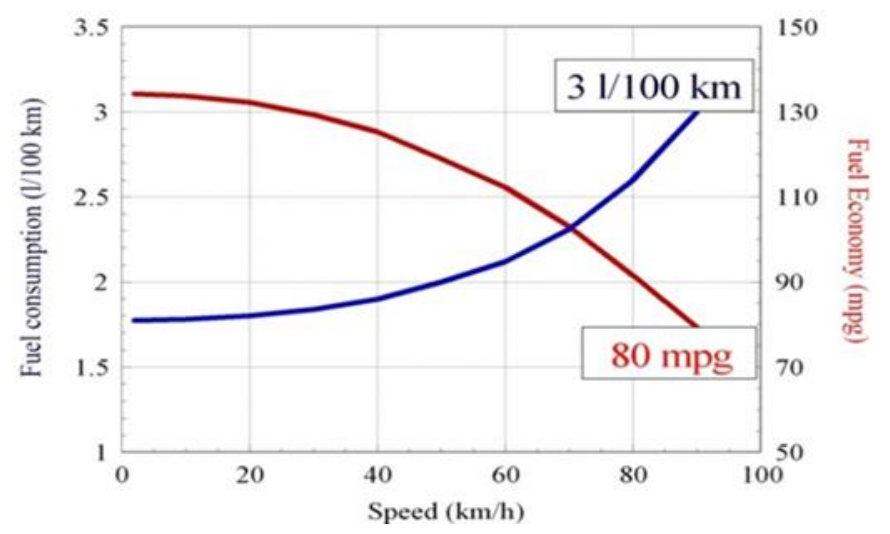

Figure 1. The main goal of PNGV was to increase fuel efficiency to up to three times from 26.6 (in 1994) to $80 \mathrm{mpg}$ (in 2003)

On September 29, 1993, the Clinton Administration (Bill Clinton, president from 1993 to 2001) announced the Partnership for a New Generation of Vehicles (PNGV). The partnership consisted of 8 federal agencies, national laboratories, universities, and the USA Council for automotive research (USCAR), which consists of Daimler-Chrysler, Ford Motor Company and General Motors Corporation. According to the PNGV Program Plan, the 
program had three key goals: improving manufacturing, implementing new technologies, and developing a "supercar" with three times the fuel economy of a baseline passenger car, while maintaining performance, safety and cost. Specifically, the program planned to increase fuel efficiency to up to three times the average of 1994 family sedans-which was 26.6 miles per gallon (up to 80 miles per gallon, i.e. $3 \mathrm{~L} / 100 \mathrm{~km}$, since 2003) -without reducing performance, safety, or affordability, Fig. $1[4,5,6,7]$.

Under the George W. Bush (president from 2001 to 2009) Administration in 2001, the PNGV program was cancelled and funding for this research was redirected to a new program, the "Freedom CAR" program, which will focus on fuel cell vehicles and the related support infrastructure.

The goal of the Freedom CAR and Fuel Partnership is the development of emission- and petroleum-free cars and light trucks. The Partnership focuses on the high-risk research needed to develop the necessary technologies, such as fuel cells and advanced hybrid propulsion systems, to provide a full range of affordable cars and light trucks that are free of foreign oil and harmful emissions - and that do not sacrifice freedom of mobility and freedom of vehicle choice, Figure 2.
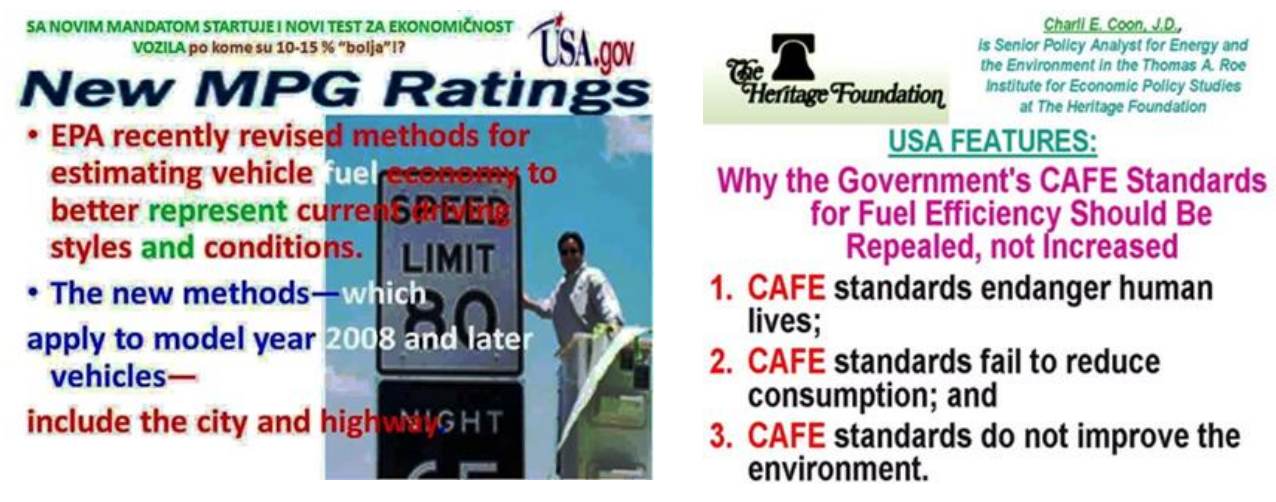

Figure 2. Freedom CAR. President. Georg W. Bush Directs Administration To Take The First Steps Toward Regulations Based On "Twenty In Ten" Goal

G. Bush in 2007 established aggressive the nation's first comprehensive Renewable Fuel Standard (RFS) program "20-in-10". The "20-in-10" program calls for reducing gasoline usage by $20 \%$ in the next 10 years. This reduction is to be achieved by "increasing the supply of renewable and alternative fuels by setting a mandatory fuels standard to require 35 billion gallons of renewable and alternative fuels in 2017" [8].

In the programme G. Bush has directly ordered the EPA agency to change vehicle tests. The EPA has changed its fuel economy testing methods to produce mileage estimates that reflect "real world" driving habits. The new testing process will significantly reduce estimated fuel economy - in some cases up to 25 percent compared to the old testing process. Ironically, EPA has already conducted tests according to new fuel economy tests for years [8]. 


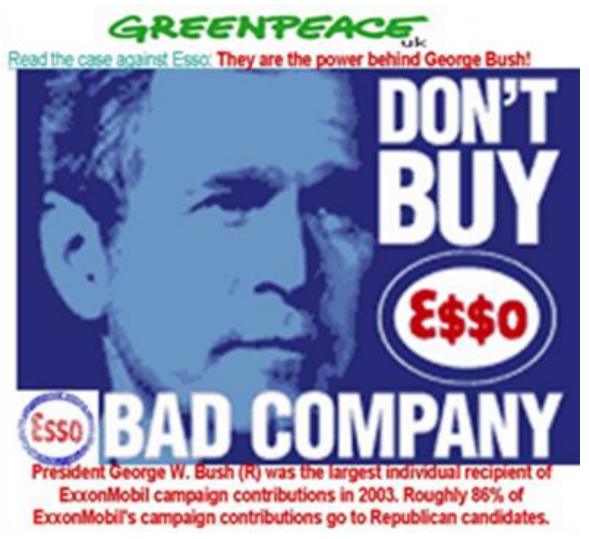

Figure 3. Exxon Mobil is the power behind George W. Bush presidential campaign [9]

Exxon Mobil is the power behind George W. Bush presidential campaign. Exxon Mobil was a large donor of the Republican Party giving over one million dollars, more than all the other oil companies. Eighty-six percent of total contributions went to the Republican Party. But Exxon Mobil, in many ways, kept its distance from the Bush presidency. Mr. Bush mostly delivered on the oil industry's agenda. Yet he seemed to want to distance himself from Exxon Mobil and Big Oil. He even declared in his 2006 State of the Union address that the United States was "addicted to oil." He hoped to be remembered for the long-term investments his administration had made in alternative energy. About Mr. Bush's hope like as presidents of both parties before him, however, he lacked the depth of conviction, the political coalitions and the scientific vision to do more than its wishes. Oil companies does not correspond to a decrease in fuel consumption so politicians are their prisoners, Fig. 3.

In June 2013, President Barack Obama (president from 2009 to 2017) put forward a broad-based plan to cut the carbon pollution that causes climate change and affects public health (Climate Action Plan). Cutting carbon pollution will help spark business innovation to modernize the USA power plants, resulting in cleaner forms of American-made energy that will create good jobs and cut the USA dependence on foreign oil. Combined with the Administration's other actions to increase the efficiency of the USA cars and household appliances, the President's plan will reduce the amount of energy consumed by American families, cutting down on their gas and utility bills.

On August 3, 2015, President Obama and EPA announced the Clean Power Plan a historic and important step in reducing carbon pollution from power plants that takes real action on climate change. Shaped by years of unprecedented outreach and public engagement, the final Clean Power Plan is fair, flexible and designed to strengthen the fastgrowing trend toward cleaner and lower-polluting American energy. With strong but achievable standards for power plants, and customized goals for states to cut the carbon pollution that is driving climate change, the Clean Power Plan provides national consistency, accountability and a level playing field while reflecting each state's energy mix. It also shows the world that the United States is committed to leading global efforts to address climate change.

Summing up his two mandates, Obama has called a meeting of the world's leaders in Paris, in 2015. According to him, that was the first time that world leaders have comprehensively solved the issues of the environment. The departing President of the UN 
Assembly, Ban Ki-Moon helped him in all matters, asking the delegates to sign a framework agreement (Fig. 4) before they leave Paris. This agreement shall enter into force in 2020, until when it is necessary to collect $\$ 80$ billion for future environment troubleshooting purposes.

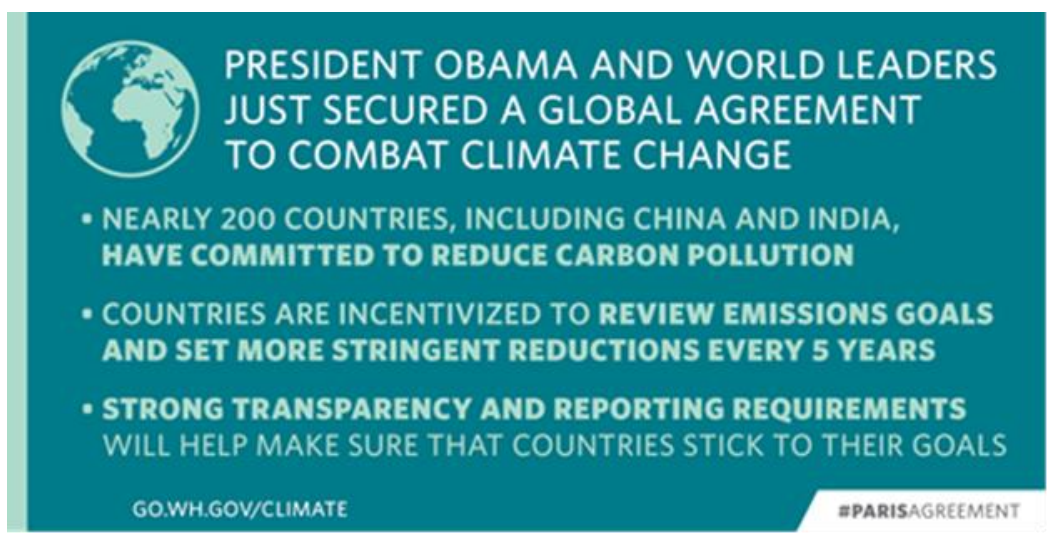

Figure 4. Paris agreement [10]

Executive Directive from October 2016 declared it as National energy awareness month [5]. The president Obama urged the people of the United States to adopt clean energy, to renew the economy and make it sustainable by celebrating this month. He noted that the Federal Government is the largest consumer of energy in the United States. It should be emphasized that the Obama administration had pledged to serve as an example in the use of clean energy and high energy efficiency. In the proclamation, it is said that this is a turning point in energy policy, so that the anomalous climate changes cannot be allowed to make chaos. New jobs can be created by developing low-carbon technologies that eliminate the worst effects. Here are the president's remarks to military defence at "Logistics 2016", Fig. 5.

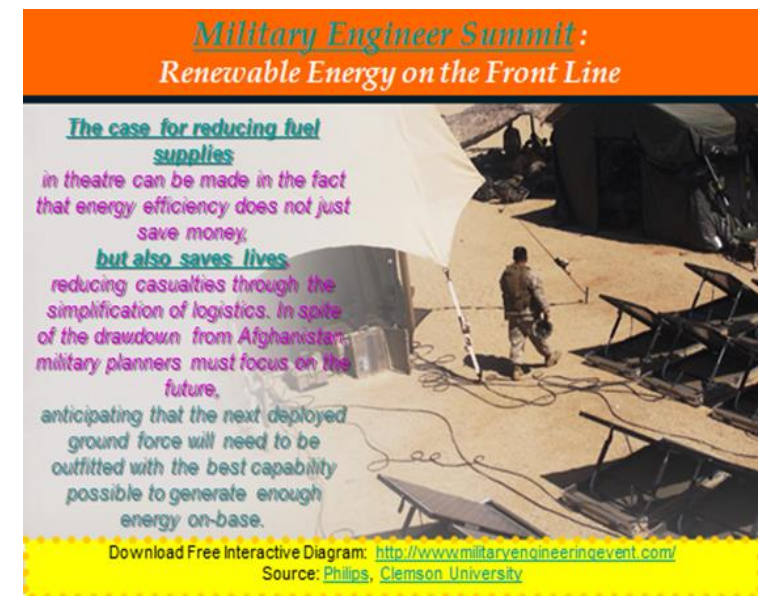

Figure 5. Renewable energy on the Front Line [11] 
Proclamation: "Better future for the ECONOMY" includes investments in energy efficiency and clean energy [12]:

- application of "GREEN DEFENSE": energy efficiency as the centre of future planning of operations and infrastructure, and the role of NATO to facilitate such changes

- reorientation to more efficient energy operations: optimization of logistics by relying and extending the possibilities.

Medium and heavy trucks play a key role in the transportation of cargo and passengers and they are the backbone of the US economy. These trucks also play a key role in other areas of society, such as the maintenance of the electrical infrastructures, collecting garbage and improvement of highway systems.

Raising the efficiency of cars in freight transport is vital for reducing oil consumption. During the presidency, Barack Obama gave many optimistic statements about the greater efficiency of passenger cars and trucks and "savings" in power consumption, Fig. 6. Most of them were too optimistic and unattainable.

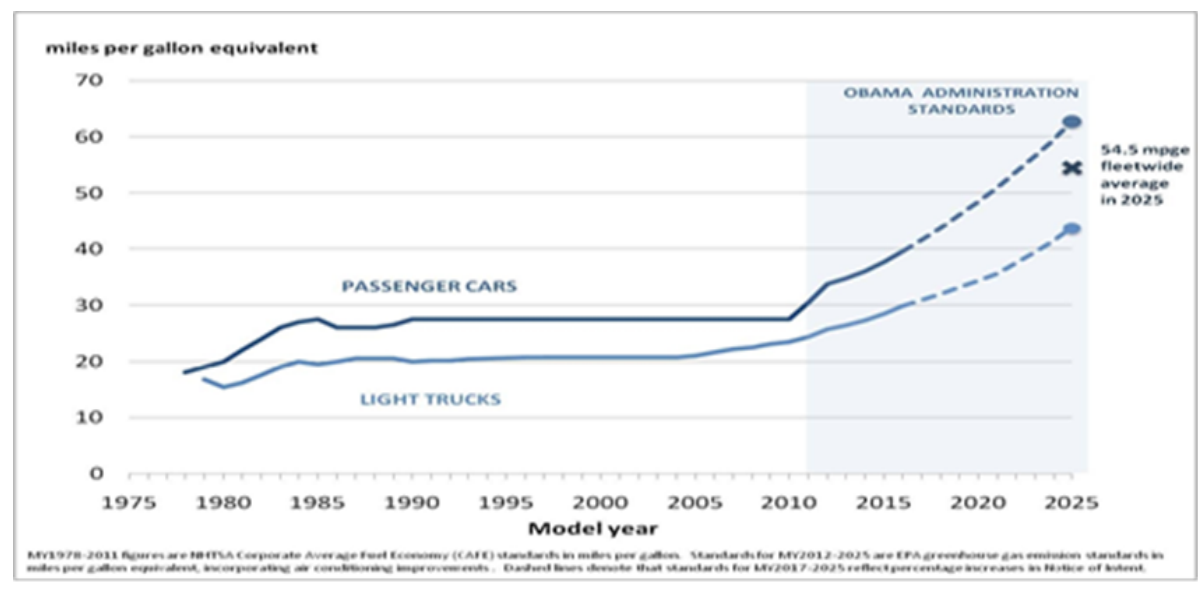

Figure 6. That's why one of the very first actions the President took in office was to direct the Environmental Protection Agency and the Department of Transportation to work with the auto industry to develop new fuel economy standards for cars and trucks

That is why one of the first President's orders was to direct Environmental Protection Agency and Department of transportation to work with the automotive industry on introduction of new standards on fuel economy program for light-duty vehicles and trucks $[13,14]$. New standards for cars and light trucks, compared to models from 2011, that should be implemented by 2025 , represent the most rigorous standards in the history of the required fuel savings. Within this, the first national program, the average fuel consumption for cars and trucks will be almost cut by half, if the average performance equivalent to 54.5 miles per gallon is reached by 2025, Fig. 6 and Fig. 7 . 


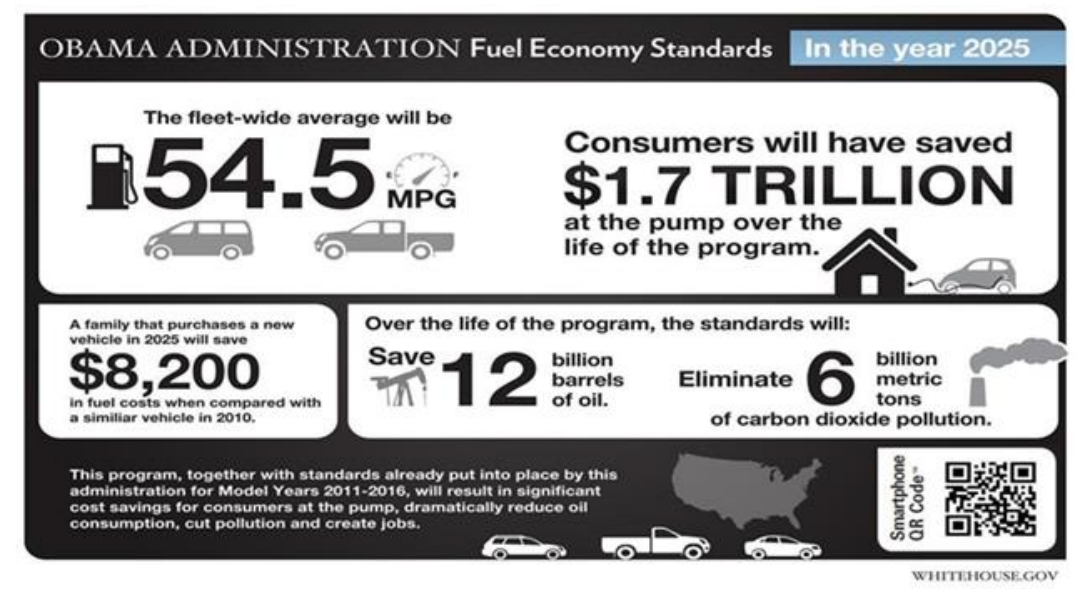

Figure 7. The President also established the first-ever fuel efficiency and greenhouse gas standards for medium- and heavy-duty vehicles, covering model years 2014 through 2018

The President has also programmed the first standard for fuel efficiency and greenhouse gases reduction for medium and heavy vehicles, by comparing models from 2014 improved by 2018. During the life of these vehicles, trucks and buses, oil consumption will be reduced by projected 530 million barrels and gas pollution emissions by about 270 million tons, saving the vehicle owners and operators about 50 billion dollars in fuel costs.

According to this project, the super tractors will improve the efficiency by more than $100 \%$ as relative increase compared to trucks from year 2009 (from 5.8 to $10.7 \mathrm{mpg}$ ), by maintaining excellent technologies for cost-efficiency and performance (Source: Office of energy efficiency, March 9th, 2016), Fig. 8, [15, 16].

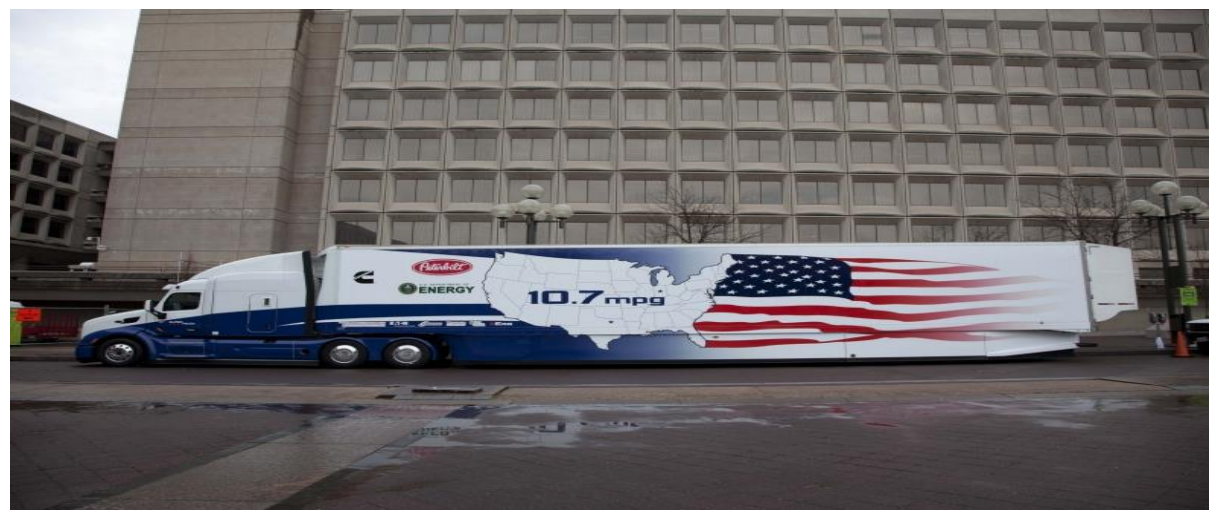

Figure 8. The US class 8 tractor trucks for heavy working conditions with Cummins engines and Peterbilt equipment with intention to achieve 10.7 miles with one gallon under real driving conditions. The truck was inspected by the Department of energy (Source: Photo Sarah Garrity) 
Volvo Press Centre Division: "We work continuously on the development of energy-efficient vehicles", says the president and chief executive of Volvo trucks, Klaes Nilsson. New Volvo truck concept is aimed at $30 \%$ reduction in fuel consumption compared to the typical trucks of such classes. Improvement of efficiency of Volvo trucks comes down to an aerodynamic design and weight reduction (source: Volvo 15, 16]).

Following Donald Trump's swearing-in (January 2017), the White House Web site was quickly updated to completely eliminate the phrase "climate change" replacing it with Trump's "America First Energy Plan,", and the Trump administration has instructed the E.P.A. to remove a page about climate change from its Web site [17]. It is not unusual for a new president to order changes to agency Web sites, or to temporarily suspend their public communications until they are brought into line with administration policy. But the executive actions taken by president Trump in his first days in office have raised alarms for the speed with which he has sought to erase Barack Obama's environmental legacy and the unusual scope of the changes $[17,18]$.

U.S. EPA, in February 2017, recall some section of the Clean Air Act, and regulations for the LD sector, and program for light-duty vehicles and light-duty trucks [19]

President Donald Trump decided that the United States will withdraw from the landmark Paris climate agreement. Trump also decided he would start talks to re-enter the accord with what he called a more "fair" deal, but was immediately rebuked by several European governments. The decision sets the world's largest economy apart from almost all other nations on Earth, and moves in opposition to many large American companies, as well. Always a showman, Trump announced the decision in a heavily teased event at the White House Rose Garden, where administration officials and conservatives applauded the move. "In order to fulfil my solemn duty to protect America and its citizens, the United States will withdraw from the Paris climate accord, but begin negotiations to re-enter either the Paris accord or an entirely new transaction on terms that are fair to the United States, its businesses, its workers, its people, its taxpayers," Trump said [20].

\subsection{The UK example}

Since 2005 Emissions of greenhouse gases have been subject to regulation under a market based mechanism known as the EU Emission Trading Scheme (ETS). This European wide policy regulates roughly half of all emissions in the EU. A finite number of allowances to emit are created and distributed. Participating installations must then surrender allowances to match the emissions they produce. Those who can cheaply and easily reduce their emissions can sell spare allowances to those who find it harder or more expensive to do so. The balance of supply and demand for allowances creates a traded price for carbon [21].

The Carbon Price Floor (CPF) is a UK Government policy implemented to support the EU wide Emissions Trading System (EU ETS) which places a price on greenhouse gas emissions. It does this by requiring heavy energy users to acquire permits for every unit of greenhouse gases they emit. These permits are called emission allowances.

Britain's decarbonisation policies are not the same as other European countries. They are much more aggressive. When, in 2007, Germany proposed the EU adopt renewable energy targets, to the horror of the Treasury and Alistair Darling's Department of Trade and Industry, Tony Blair gave Britain the most aggressive wind and solar targets of any member state. With Blair gone, Gordon Brown's government rejected proposals for a unilateral carbon price floor. The idea was to prop up the price of carbon allowances credits 
under the EU's Emissions Trading Scheme. This sensible approach was abandoned by the Coalition government. To show climate leadership, the Coalition Agreement promised a carbon price floor, which duly came in George Osborne's 2011 budget [22].

Following the implementation of the Carbon Price Floor in the UK, the European Commission considered, but ultimately rejected, a similar system to reform the EU ETS. This option was also considered by France but the proposal has been dropped. Thus way, UK energy generators will face carbon costs six times higher than their European counterparts. This poses an interesting dilemma for Treasury as it will result in more revenue than it might otherwise expect from the EU ETS, but imposes greater cost on British industry compared to European competitors [21, 22, 23].

In fact, the impact of the carbon price floor on electricity costs is greater than the sums reaped by the Exchequer, as it gives investors in low-carbon capacity, especially nuclear, the ability to price up to the floor. Rather like airport duty-free shops, it turns them into quasi-tax collectors lining their own pockets [22].

This huge annual windfall helps explain how in 2015 the owners of Britain's nuclear power stations collected $£ 994 \mathrm{~m}$ in operating profits. Over the same period, the Big Six's gas and coal-fired power stations, which generated $65 \%$ more electricity than nuclear, racked up $£ 405 \mathrm{~m}$ in operating losses. The carbon price floor is the principle reason why coal generation, Britain's cheapest source of electricity, is being forced off the grid, even though Germany expects to keep operating its coal-fired power stations until 2040 [21, 22].

Driving down energy consumption and pushing up high-fixed-cost generating capacity is a formula for ever-rising electricity prices? Between 2013 and 2015, the price of fossil fuels used by the Big Six (G6) to generate a megawatt hour (MWh) of electricity fell by $20.1 \%$. Network costs rose by $9.8 \%$ and green and other government levies rose by a whopping $26.6 \%$ per MWh of electricity supplied by the Big Six. While the rest of the world enjoyed the benefits of plunging fossil fuel prices, electricity prices in the UK rose by $4.2 \%$. This is not the fault of the Big Six. The blame rests fairly and squarely on government policies $[21,22]$.

Therefore, headlines in newspapers are becoming more and more frequent, such as: "False claims on low-carbon energy are damaging UK" [21].

\section{CRITICAL REVIEW OF POLITICAL ECOLOGY}

The critical verification of political ecology is based on the J. Robert Oppenheimer's words: "We do not believe that any group of people is sufficiently or wise enough to work without supervision or without criticism. We know that the only way to avoid the mistake is to discover it, that the only way to It reveals it freely to inquire, we know that it will be wrong to reveal and undermine in secret" [24].

In the following text, during analysing the attitudes of the political ecology, some questions will be asked and some answers will be get.

The misuse of ecology is the introduction of the concept of "renewable energy resources", the "green economy" and many "eco" prefixes with the wrong content. Military war strategies impose the development of these areas. It is well known that countries rich with raw materials do not have well-developed infrastructure [25, 26, 27]. This is why "renewable energies" like: Sun, wind, hydro energy and biomass are very important in the war. All projects that receive scores of NATO-importance are due a large financial backing. 
A better future of the economy and the nation needs investments in energy efficiency and clean energies. Good financial support for research and development of the energy sector will help not only to protect the environment and support the community, but will also contribute to the global competitiveness and national security. Innovations in energy technologies reduce dependence on oil, boost the economy and reduce the danger of pollution that causes climate change $[16,28]$.

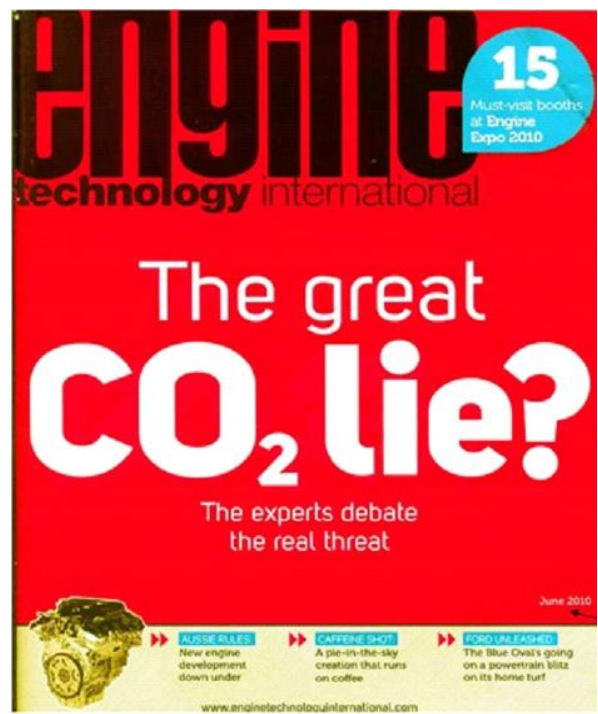

Figure 9. More and more often are heard the other side of the story emissions of carbon dioxide

Geophysics is a natural science that deals with physical processes and the physical characteristics of Earth and its space environment, using quantitative methods for their analysis.

There is no convincing scientific evidence that anthropogenic release of carbon dioxide, methane, or other greenhouse gasses is causing or will, in the foreseeable future, cause catastrophic heating of the Earth's atmosphere and disruption of the Earth's climate. Moreover, there is substantial scientific evidence that increases in atmospheric carbon dioxide produce many beneficial effects upon the natural plant and animal environments of the Earth. Oregon Petition, from the Oregon Institute of Science and Medicine, signed by over 17,000 international scientists including more than 2000 of the world's leading climatologists, meteorologists and planetary / atmospheric scientists [29].

Carbon Dioxide currently at $370 \mathrm{ppm}$, for it to be dangerous it would have to be at $15,000 \mathrm{ppm}$. This could not be reached even if every fossil fuel was burned. Thousands and thousands of studies show that higher levels of $\mathrm{CO}_{2}$ are good for plants. Many scientists believe plants still are not getting enough $\mathrm{CO}_{2}$. Tomato farmers using exhaust from electricity to grow their tomatoes. Vegetation loses less water under higher $\mathrm{CO}_{2}$ levels, meaning vegetation in drought prone areas will live longer and produce more. Rice (the most eaten food in the world) was shown to increase mass and use less water with higher 
$\mathrm{CO}_{2}$ levels. Meaning the most important food in the world highly benefits from $\mathrm{CO}_{2}$ increase, Fig. 9.

Global warming not primarily caused by $\mathrm{CO}_{2}$, says Donald Trump's environment chief Scott Pruitt [30].

\section{LIFE OR SCIENTIFIC ECOLOGY}

As it is well known, life on Earth is possible due to the existence of "natural greenhouse effect". Svante Arrhenius has developed a theory to explain the ice age, and in 1896, he was the first scientist who was trying to explain how changes in the level of carbon dioxide in the atmosphere can change the temperature of the surface by greenhouse effects. In its original form, the law Arrhenius law of "greenhouse gases" is as follows: If the amount of carbonic acid $\left[\mathrm{H}_{2} \mathrm{CO}_{3}\right]$ increases geometrically, the temperature will increase by arithmetical progression. Equivalent formulation of Arrhenius "greenhouse gases" dependence is still used today.

The natural greenhouse effect phenomenon, primarily water vapour, $\mathrm{H}_{2} \mathrm{O}$, carbondioxide, $\mathrm{CO}_{2}$, and some other gases (such as methane, $\mathrm{CH}_{4}$, nitrogen oxide $-\mathrm{NO}_{\mathrm{x}}$ and ozone, $\mathrm{O}_{3}$ ) allows sunlight to penetrate to the Earth:

- to light the Earth,

- to maintain photosynthesis that enables the life of flora and fauna, and

- to keep infrared heat in the atmosphere.

All of these three phenomena sustain our planet as moderately warm, which is a condition for the normal physiological functions of all living organisms. The absence of greenhouse gas emissions would reduce the temperature of our planet similar to other lifeless planets of our solar system [26, 27].

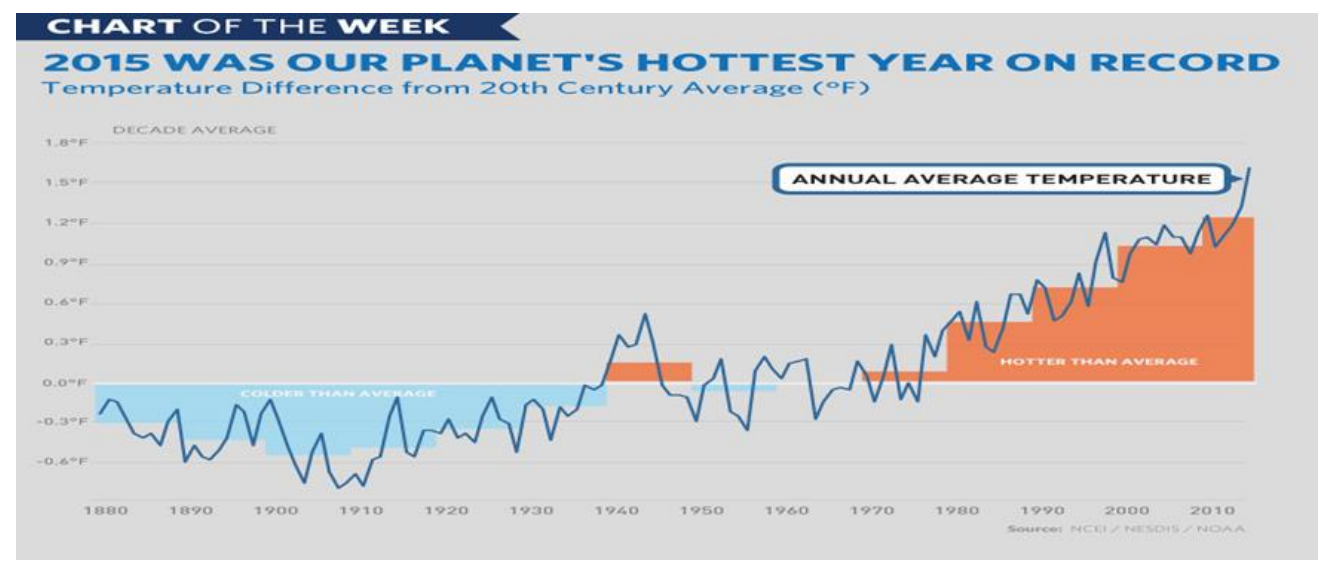

Figure 10. Chart of the week: 2015 Was Earth's Hottest Year on Record January 25, 2016 at 3:01 PM ET by wh.gov/climate 
Measurement of global average temperature of air had started in the late 1800's. According to National Oceanic and Atmospheric Administration (NOAA), in 2015, global average temperature of surface air was $1.62{ }^{\circ} \mathrm{F}\left(0.90^{\circ} \mathrm{C}\right)$ above the level in the 20th century or the highest of all levels from 1880 to 2015, overcoming the previous record in 2014 by $0.29{ }^{\circ} \mathrm{F}\left(0.16^{\circ} \mathrm{C}\right)$, Fig. 10 . According to NOAA, this is the largest overstepping of mean annual global temperature [31]. Since 2001, our planet has witnessed 15 of 16 hottest years ever recorded. If we want to avoid the disastrous consequences of climate change, we need to dedicate ourselves to this problem now.

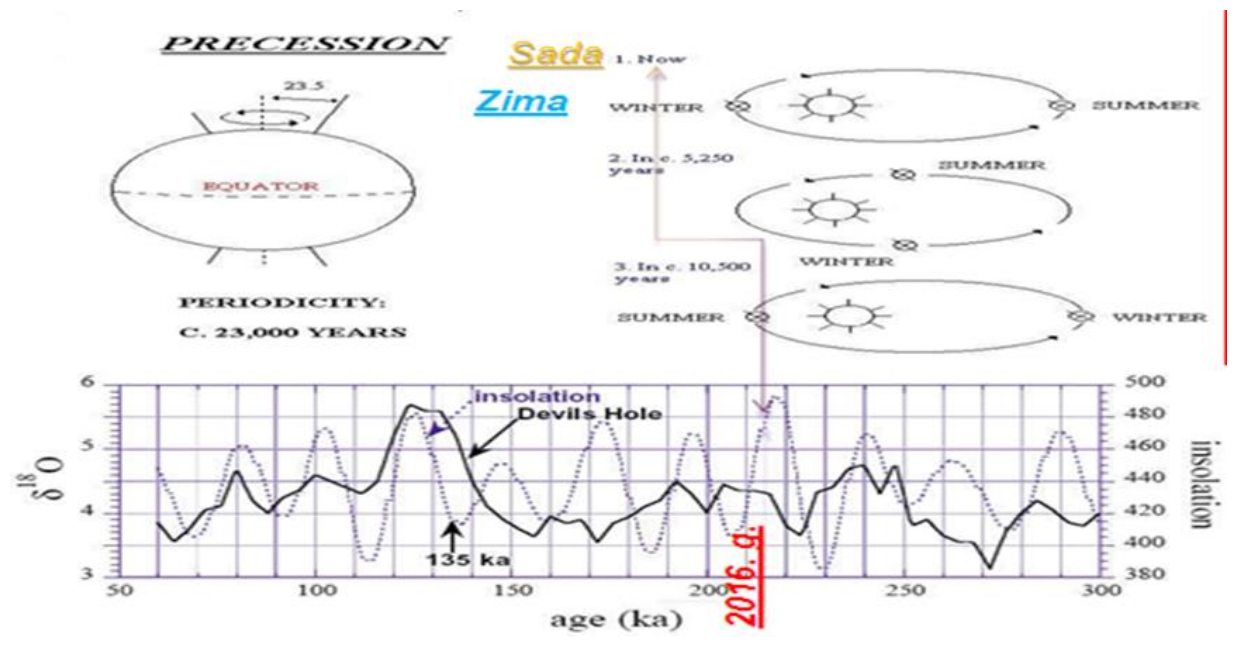

Figure 11. For about 50 years M. Milanković theory was largely ignored

The cosmic laws define global relations. For a more detailed understanding of global relations, one should, once again, take a look at the work of our "cosmic" scientists, Milutin Milankovic [32, 33]. Simplified definitions of environmental protection say that the basic problems are:

- Global warming,

- Thickening of the Earth's layers (by three- and multiple-atomic gases) and future lack of oxygen in the atmosphere!

- Technologies of environmental protection are the ones that are conducted with the lowest consumption of oxygen - without oxygen, there is no life,

- All human activities, at the same time and every day, are changing genetic basis for sustaining the life on Earth.

The future is similar to Venus and Mercury because they are too close to the Sun and overheated. Other planets are far from the Sun and too cold. While reading the standpoint of the President Obama, Fig. 4, it seems that he looked at the lists of $\mathrm{M}$. Milankovic, Figure 11.

Reserves of fossil fuels are not sufficient, Fig. 12. There is a visible alternative for vehicle drive - electrical motors, Fig. 13. The fact that Nikola Tesla's ideas of remote and 
wireless transmission of energy are not remembered nor materialized is not an obstacle to constantly try such a thing.

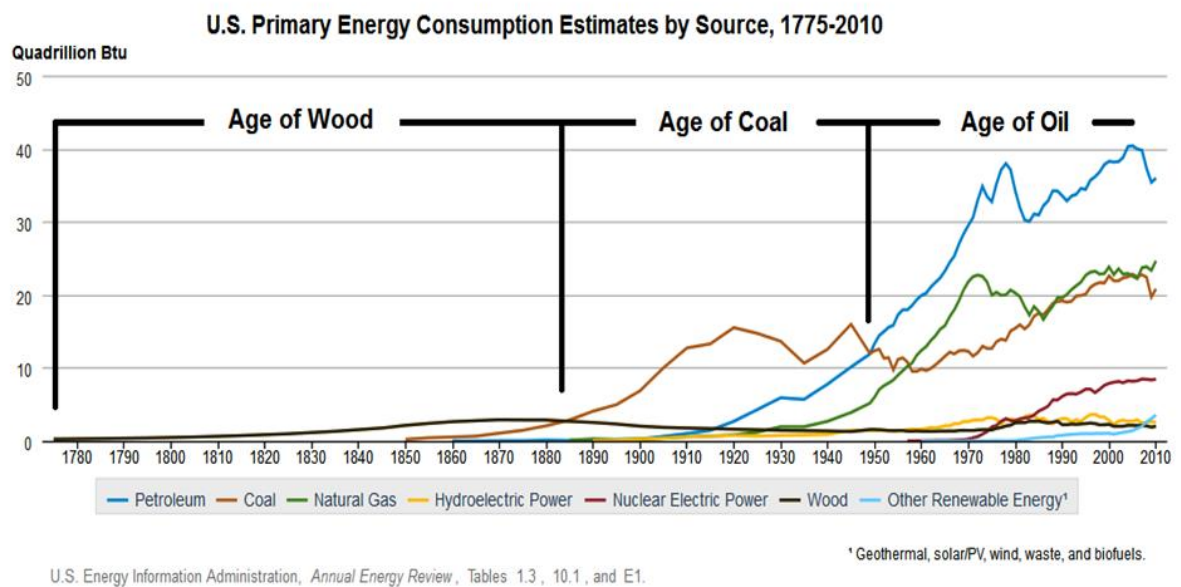

Figure 12. USA primary energy consumption
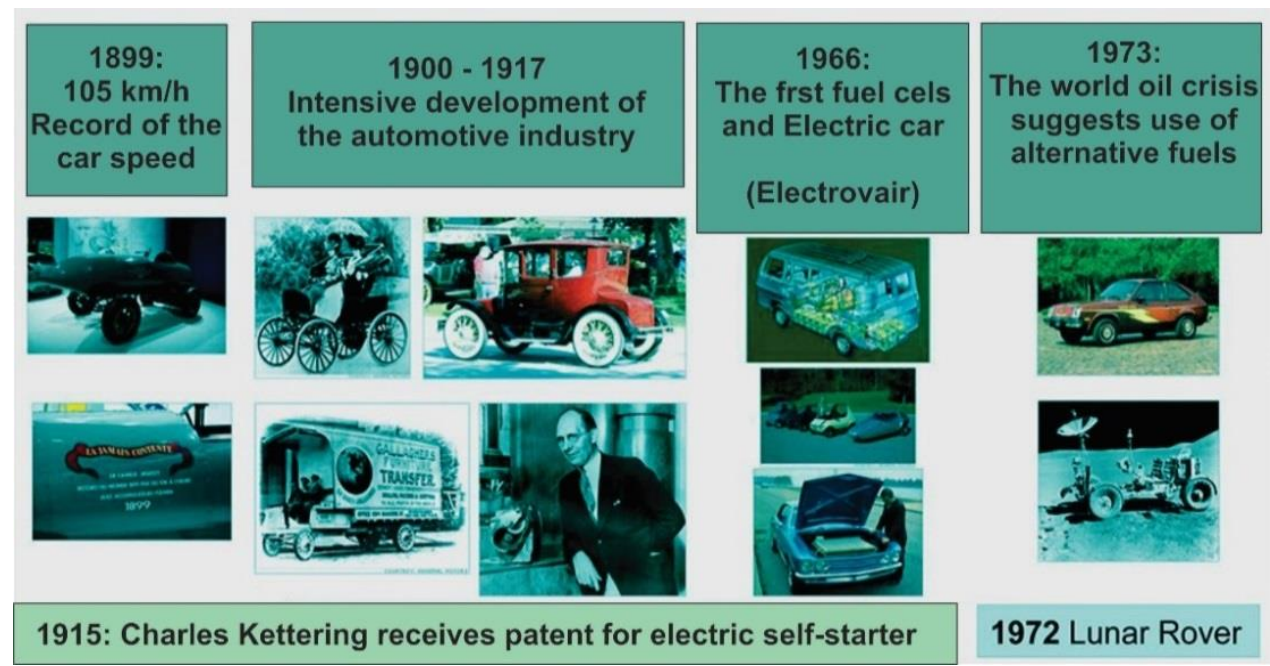

Figure 13. Energy voltage in vehicles between $12-48-96-400-800 \mathrm{~V}$

Battery power for vehicles had existed 100 years ago, until mass production of internal combustion engines and fossil fuels had reduced it to individual cases, Figures 14 to 16. 


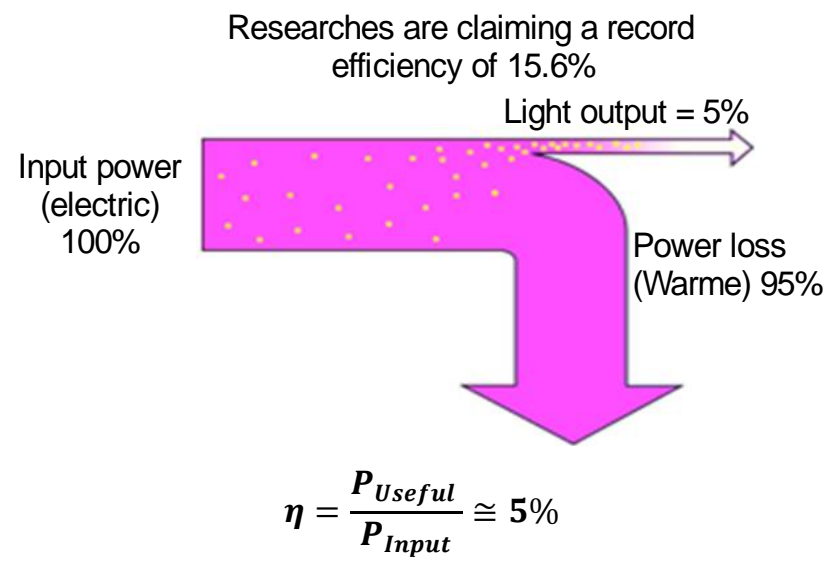

Figure 14. Solar energy: Researchers claim that record efficiency of $15.6 \%$ is possible in laboratory conditions

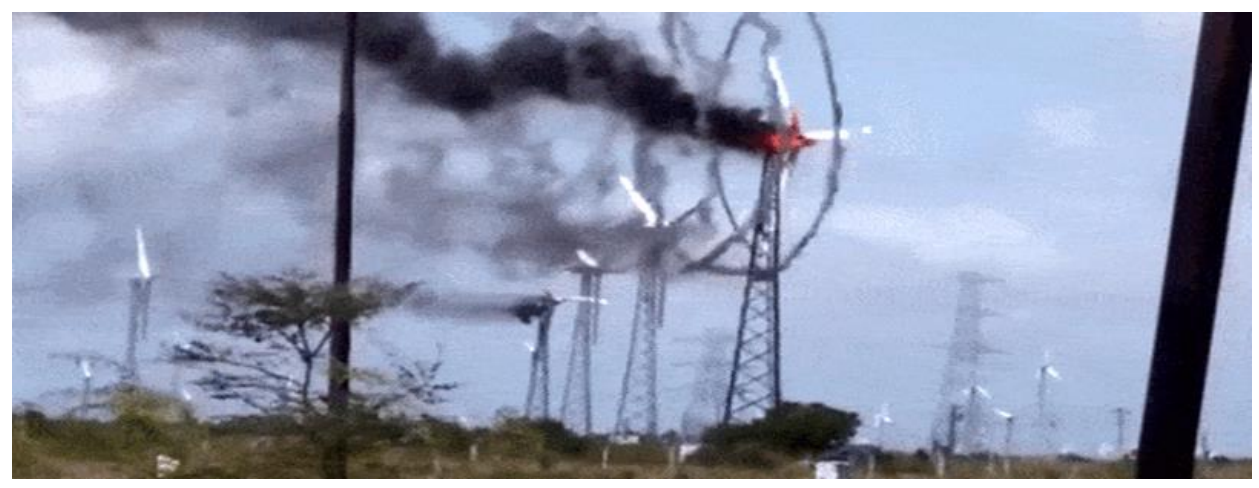

Figure 15. Wind energy: without efficient energy balance, there are no eco-grades
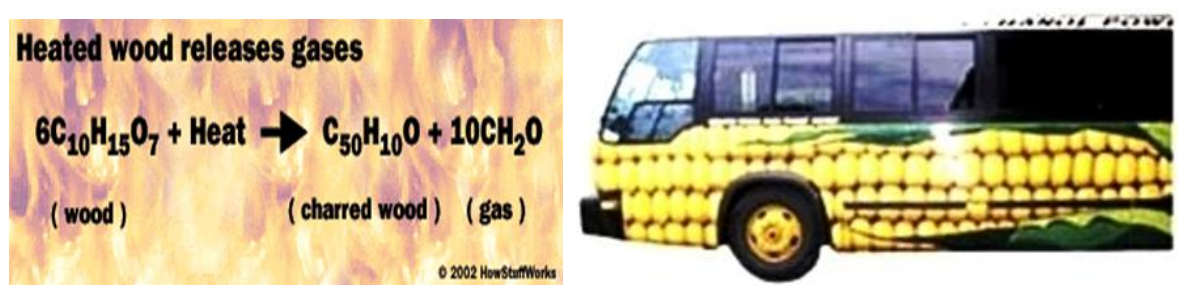

Figure 16. BIO ENERGY: the biofuel system has aggravated rather than helped to mitigate global warming, even for systems where the life-cycle analyses indicate a positive influence on net greenhouse gas emissions 
"Hydropower vision" believes that the rise in power from hydroelectric plants, from $101 \mathrm{GW}$ capacities in 2015 to nearly $150 \mathrm{GW}$ by 2050, is realistic in the United States. World reserves are still around $2 \%$.

Bio energies do not help in mitigation of global warming, even for systems where the life-cycle analysis indicates a positive influence on net greenhouse gas emissions.

\section{CONCLUSIONS}

Human activities leave lasting consequences on the Earth and the environment! There is no "ecological life", but only "ecological behaviour". There is no "green energy", but only a reasonable engaging of energy sources with a lot of eco-friendly concessions. The overall environmental pollution of air, water and land leads to compromising the genetic basis by uncontrollable changes around the world on which our planet rests.

Ecological consciousness and life rules are at the base of every country in the world. Identifying the environmental values of each product is the first step in environmental thinking. Once upon a time, the companies had rarely respected it, but that usually eliminates the huge, amazing amount of waste. The basic maxims of sustainable life on our planet are: NOTHING TOO MUCH AND MODERATION IN ALL THINGS. (Quote: ancient Greek Delphi).

To our knowledge, our language does not contain the correct scientific definitions of words on the meaning of energy sources "renewability" or "repetition". Terminology emphasizes the extreme differences when it comes to the environment. Technically, all sources of energy are repeated and are not renewable. It is the question of different time intervals - the important distinction between renewable and non-renewable sources of energy is the speed of their repetition. Definition of sources of energy may be the only such repeatability, or reintegration should be regarded integrally, with appropriate technologies and plants for their transformation. For example, unmanaged installation of wind power plants or solar panels leaves us immediately with no usable land, before all fossil fuels are effectively spent. In addition, windmills and solar panels are heating up the surrounding area and are working with very low efficiency in terms of preserving the environment!

\section{ACKNOWLEDGMENT}

The paper is a result of the research within the project TR 35041 financed by the Ministry of education, science and technological development of the Republic of Serbia.

\section{REFERENCES}

[1] William S. Abruzzi, The Myth of Chief Seattle, Human Ecology Review, Vol. 7, No. 1, pp. 72-75, 2000.

[2] Clean Air Act Text, https://www.epa.gov/clean-air-act-overview/clean-air-act-text, accessed on 06.07.2017.

[3] UNITED NATIONS FRAMEWORK CONVENTION ON CLIMATE CHANGE, UNITED NATIONS 1992, https://unfccc.int/resource/docs/convkp/conveng.pdf, accessed on 06.07.2017. 
[4] United States Council for Automotive (USCAR), http://www.uscar.org/guest/index.php, accessed on 02.06.2016.

[5] Pešić R., et al: "The experimental VCR diesel engine and determination of double Vibe function parameters". The 9th International Congress on Automotive CAR 2005, Pitesti, Romania, Proceedings ISBN 973-690-450-4, Paper CAR20051028, , 2-4 November 2005.

[6] R. Pešić, S. Veinović, E. Hnatko \& K. Golec: "Environmental challenges to the passenger car power-plant of the future", Mobility \& Vehicle Mechanics, International Journal for Vehicle Mechanics Engines and Transportation Systems, Volume 25 Number 1, YU ISSN 1450 5304, March 1999.

[7] R. Pešić, S. Petković, E. Hnatko, S. Veinović: Interdisciplinary contents of the project "the minimum fuel consumption car", Proceeding (Pešić R., Lukić J.) International Congress Motor Vehicles \& Motors 2012, Kragujevac 3rd -5th October 2012, pp. 289- 297, 2012.

[8] Twenty in Ten: Strengthening America's Energy Security, https://georgewbushwhitehouse.archives.gov/stateoftheunion/2007/initiatives/energy.html, accessed on 02.06.2016.

[9] Boycott Exxon Mobil Stations!, http://www.thepetitionsite.com/takeaction/771/ 633/715/.

[10]FACT SHEET: U.S. Hosts World's Energy Ministers to Scale Up Clean Energy and Drive Implementation of the Paris Agreement, https://www.whitehouse.gov/the-press-office/2016/06/02/fact-sheet-us-hostsworlds-energy-ministers-scale-clean-energy-and-drive, accessed on 02.06.2016.

[11] http://www.militaryengineeringevent.com/, accessed on 02.06.2016.

[12] Going Solar Saves Nellis Air Force Base over \$1 Million a Year on Energy Costs, https://us.sunpower.com/commercial-solar/case-studies/nellis-air-force-base/, accessed on 02.06.2016.

[13] VEHICLE TECHNOLOGIES OFFICE, http://energy.gov/eere/vehicles/vehicletechnologies-office, accessed on 02.06.2016.

[14] A Historic Commitment to Protecting the Environment and Reversing Climate Change, https://www.whitehouse.gov/the-record/climate, accessed on 02.06.2016.

[15] Volvo Trucks' new concept truck cuts fuel consumption by more than $30 \%$, http://phys.org/news/2016-05-volvo-trucks-concept-truck-fuel.html, accessed on 02.06.2016.

[16] SuperTruck Making Leaps in Fuel Efficiency, http://energy.gov/eere/articles/supertruck-making-leaps-fuel-efficiency, accessed on 02.06.2016.

[17] Maya Kosoff, TRUMP WHITE HOUSE ORDERS E.P.A. TO DELETE CLIMATE-CHANGE WEB PAGE, JANUARY 25, 2017, http://www.vanityfair.com/news/2017/01/trump-white-house-orders-epa-to-deleteclimate-change-web-pages, 2017.

[18] Review of the Clean Power Plan, https://www.federalregister.gov/documents/ 2017/04/04/2017-06522/review-of-the-clean-power-plan, 2017.

[19] U.S. EPA recall program for light-duty vehicles and light-duty trucks http://www.theicct.org/sites/default/files/publications/EPA\%20Recall\%20LDV\%2 0Briefing_ICCT_vF_08022017.pdf_06.07.2017.

[20] Tom DiChristopher and Jacob Pramuk, Trump: US is withdrawing from Paris climate agreement but wants to renegotiate, https://www.cnbc.com/2017/06/01/trump-announces-paris-climate-agreementdecision.html, accessed on 06.07.2017. 
[21] The UK Carbon Floor Price, https://sandbag.org.uk/wp-content/uploads/2016/11/ Sandbag_Carbon_Floor_Price_2013_final.pdf, accessed on 05.08.2016.

[22] Rupert Darwall, False claims on low-carbon energy are damaging UK, http://www.telegraph.co.uk/business/2017/03/23/false-claims-low-carbon-energydamaging-uk/2 accessed on 06.07.2017.

[23] France to set unilateral floor price for carbon emissions, http://www.reuters.com/article/us-france-carbon-idUSKCNOXN1C6.

[24] J. Robert Oppenheimer, "The Scientist in Public Affairs: Encouragement of Science", Bulletin of the Atomic Scientists, v.7, No1, p. 6-8, (Jan 1951).

[25] Gruden, D. et al:Traffic and environment. Springer Verlag. Berlin Heidelberg, 2003.

[26] R. Pešić, S. Veinović: Transport ecology and global climate change, X Anniversary International Conference on accomplishments in electrical, mechanical and information engineering DEMI 2011, (Keynote Lecture) Proceeding ISBN 97899938-39-36-1 (Editor in Chief G. Globočki-Lakić), Banja Luka, pp. 7-20, May 2011.

[27]R. Pešić, S. Petković, E. Hnatko, S. Veinović, Interdisciplinary contents of the project "the minimum fuel consumption car", International Congress Motor Vehicles \& Motors 2012, Kragujevac, 2012, 3rd -5th October 2012, pp. 289- 297.

[28] OSCAR DELGADO, NIC LUTSEY, ADVANCED TRACTOR-TRAILER EFFICIENCY TECHNOLOGY POTENTIAL IN THE 2020-2030 TIMEFRAME, http://www.theicct.org/sites/default/files/publications/

ICCT_ATTEST_20150420.pdf .

[29] Petition project, - http://www.oism.org/pproject/ , accessed on 2011-04-07.

[30] Scott Pruitt, Global warming not primarily caused by $\mathrm{CO}_{2}$, http://www.abc.net.au/news/2017-03-10/new-epa-chief-says-man-made-co2-notto-blame-for-global-warming/8342052, 2017.

[31] Meteorological Technology International, http://www.ukipme.com/pubmeteorological.php, accessed on 02.06.2016.

[32] Milutin Milankovitch - http://earthobservatory.nasa.gov/Features/Milankovitch/, accessed on 7.6.2016.

[33] Spasova D. et al, Milutin Milankovitch a traveller through distant worlds and times. Ministry of Environmental Protection of Republic Serbia, Belgrade, 2007. 